\title{
Political Parties and the Production of an Islamist-Secularist Cleavage in Turkey
}

$\mathrm{T}$ his study demonstrates how profoundly Turkey's main social cleavage - Islam versus Secularism is produced and reproduced by political parties in their attempts to form a coherent sociopolitical bloc as a basis of mass support.

\section{Introduction}

The article aims to demonstrate how profoundly Turkey's main social cleavage - Islam vs. secularism - is produced and reproduced by its political parties. I will analyse the role of political parties in producing this cleavage at the level of the official programmes of the Justice and Development Party (the Adalet ve Kalkınma Partisi orAKP) and the Republican People's Party (the Cumhuriyet Halk Partisi or CHP). The main purpose is to challenge the paradigm which understands social cleavages to be part of a 'social structure' that exists prior to political articulations. According to this standard perspective, social cleavages create the demand for political parties.

An often-repeated claim about Turkey's politics is that the conservative centre-right parties, which have won nearly all the elections since the establishment of a multi-party democracy in 1950, represent the 'natural', religious-conservative preferences of the majority. I believe there is something in this explanatory model that needs to be further scrutinized. Otherwise we end up with a simplistic conclusion according to which religious-conservative parties are destined to win elections in Turkey simply because they represent an already-existing cultural conservatism of the majority. The traditional mode of explanation presupposes that the other main constituency - the secular - is based on the natural preferences of a secular-minded minority. This is also problematic because the more or less coherent secularist constitu- ency would hardly exist in its enduring form without particular political articulations. This article argues that the cleavage is based on the logic of a legitimation of power through opposing attempts at political mobilisation, and thus cannot be reduced to presumed pre-political social and economic structures.

\section{The production of social cleavages at the level of official party programmes}

In political science, parties have often been seen to be simply reflecting the preferences and social divisions of a given society, while the cleavages themselves have been understood as being more profound and part of a large-scale explanatory category of the 'social. However, it can be argued that political parties are central to the production of social cleavages as they establish institutions capable of naturalizing class, ethnic, and religious formations as a basis of social division 'by integrating disparate interests and identities into coherent sociopolitical blocs' (De Leon et al. 2009: 194-5).

In their well-known work on cleavages and party affiliations, Seymour M. Lipset and Stein Rokkan (1967) emphasise that political parties help to crystallize and make explicit conflicting interests by developing a rhetoric for the translation of contrasts in the social structure into demands and pressures for action or inaction. That existing social divisions do not necessarily become the basis for political struggle is to some degree recognised by preceding scholarship. Octavio Amorin Neto and Gary W. Cox (1997) have defined social cleavages as enduring social differences that might become politicised, or might not. On the other hand, Michael Gallagher and others (1992) have defined cleavage as a social division in which the groups involved are conscious 
of their collective identity partly because it is an organisation that gives expression to this identity. Even though Lipset and Rokkan can said to be fully aware of the role parties have in making conflicting interests explicitly expressed, their perspective, defined as a research problem which asks how does a sociocultural conflict gets translated into an opposition between parties?' (Lipset and Rokkan 1967: 26) presumes that these sociocultural conflicts exist prior to political parties.

This article suggests that divisions constituting the basis for social cleavages are indeed produced within the social process, but that in modern societies this social process is political from the very beginning. Here I follow Colin Hay who asserts that

The political should be defined in such a way as to encompass the entire sphere of the social. The implication of this is that events, processes and practices should not be labelled 'non-political' or 'extra-political' simply by virtue of the specific setting or context in which they occur. (Hay 2002: 3)

Thus, the existence of a social cleavage is ultimately possible only through an intertextual process where different political parties espouse different group identities in an interdependent, relational process. Of course, a counter argument would assert that there need to have been social divisions within the Ottoman society existing at the time of the establishment of the first modern parties after 1908. Indeed, there definitely were different communities and thus also social divisions in the Ottoman realm before the birth of the modern parties, but one needs to seriously consider the possibility that these were qualitatively different from the ones that have been subsequently generated. According to Fred Halliday (2005: 7) the Young Turk revolution of 1908 was 'arguably the greatest turning point in the modern history of the Middle East'. After 1908, all previous collective identities have been thoroughly transformed within the process of nation building. As Robert D. Lee puts it,

The modern doctrine of social contract proposes that states should be the creation of peoples who already have a common identity... the question, then, of what constitutes identity within the nation becomes a much more critical issue than it ever was in the age of empire... politics has already reshaped religion in this sense, because the triumph of the nation-state shapes the question of identity. It creates an issue where there was none. (Lee 2010: 12-13)

This is why it can be justifiably argued that traditional, collective identities were produced and experienced through very different mechanisms and practices. They were reproduced in local settings, and they hardly had any unifying features beyond the small units composed of village communities, tribes, clans, religious sects, and so forth. Even the great religious traditions with universal pretensions and a common discourse, such as Islam, were lived and experienced locally, as there was no reason to narrate these collective identities within the national, centralised structure. The definition of a social cleavage as it is understood in the present study can thus be presented in the following form: a social cleavage, in a modern nation state, is a social division in which the groups involved are conscious of their collective identity most of all because there are organisations - political parties - that through an intertextual process produce and reproduce the core elements of such a group identity.

The research question can thus be expressed in a simple formulation: how is the Islamist-secularist cleavage intertextually produced and reproduced in the official programmes of Turkey's main political parties? A political party programme can be seen as a way of integrating various interests into a general political project transformed into a programme, for which any given party campaigns to receive the support of a majority. In this sense party programmes can be seen as explicit textual expressions of integrating different interests and identities into an aggregated form. The party programmes fulfil in particular two main functions. On the one hand, they aim to articulate the interests of the population, and on the other hand, they orientate and influence the opinions of the citizens, forming the public will. This is to say that in this study Turkey's main social cleavage is analysed at the level of key political texts, as an arena of an interplay between main parties' official programmes.

Intertextuality refers to the idea that as texts, party programmes gain their meaning only in relation to other party programmes. Intertextuality asserts that no text has a meaning - or even existence - by itself, but only in relation to other texts. Further, intertextuality denotes those explicit and implicit relations that any particular text has with past, present, and possible future texts (Allen 2006: 1-3). To develop this idea in terms of social cleavages, one can argue that no political group identity has significance 
by itself but only in relation to other group identities, reproduced by other major political parties. As Graham Allen (2006: 19) notes, 'all utterances are dialogic, their meaning and logic dependent upon what has previously been said and how they will be received by others.

Political parties aiming to secure mass support operate within the political system of a nation state. This is why their ideologies are embedded in the institutions and the ideology of the nation state. The intertextual production of major social cleavages thus refers to a process where the national characteristics offered by one political party as essential, defining factors are being formed against alternative versions offered by other parties. These narratives and their inherent cleavages become social reality only when they are acted upon and responded to in the intertextual process, constituting one another by acts of negation - 'we, as a nation, are by nature like this' is credible only when there is a competing version with different characteristics - 'we, as a nation, are not like that'.

Thus, the existence of religious-conservative and secular constituencies in Turkey implies that parties 'interpellate', to use Louis Althusser's (1993) term, each constituency through a narrative of the nation defined by its main, essential characteristics. In order to make this clearer, the concept of interpellation needs to be attached to that of an 'implied reader'. The implied reader situates in the text as an ideal (subject) position most easily available to the reader. In other words, the implied reader is called into being by the ideological text, which asks to be read in particular way (Scholes 1975: 13). This is the mechanism through which a group of discrete individuals with a range of preferences are brought together under one defining denominator. In order to investigate how this process occurs at the level of individual parties, this study engages in a close reading of their ideological narratives' main textual expressions, the official party programmes. The problem with this approach seems to be that the party programmes are often rather general descriptions of the major policy goals and principles, and thus not very revealing in terms of the most hotly-debated political issues taking place in the society. However, the official programmes' main function is precisely to win over as many voters as possible. In this sense the generalisations and attempts at building a centrist, easily accepted ground make them the most significant articulations of larger sociopolitical blocs, brought together under a common, defining denominator.
These defining denominators - and, conversely, politicised social divisions - written into the party programmes are best analysed by concentrating on the implicit and explicit historical interpretations they entail. This is based on the conviction that the building of a common, defining denominator can only take place by accounting for the past of the national political community, that is, by demonstrating through an historical account where we come from, who we are, and what is our 'true nature' (Hodgkin and Radstone 2003). This requires investigating the main narrative tropes of these contested pasts.

\section{The AKP and the production of an Islamic constituency}

The ideological pre-history of the Justice and Development Party (AKP) can be traced back all the way to the last decades of the Ottoman Empire. The AKP has been variously labelled Islamist, Post-Islamist, Neo-Islamist, Muslim-Conservative and Conservative Democrat in the existing literature (Yavuz 2009: 1-2). Even though these various definitions do point out interesting aspects of the AKP, they are of secondary importance when compared to the main discursive fault line in the history of the Republic, namely, between those who adhere to the unambiguous concept of modernity being essentially secular by nature, and those who oppose this view. This evaluation is justified on the grounds that modernisation is inextricably embedded in secularisation and vice versa. This does not mean that religious revivalism is totally anachronistic, however: it can be seen as a product of the modernisation process itself, as a collective attempt at re-enchantment in the context of an overall disenchantment. In this sense, it can be defined as an alternative or supplementary to nationalism as an instrument of re-enchantment (Delanty and O'Mahony 2002).

The AKP is a relative newcomer in Turkish politics, having been founded in 2001. Its roots lie firmly in the Milli Görüş movement, the Turkish tradition of political Islam (Atasoy 2009: 6-7). The AKP, however, has renounced its Islamist past and defines its ideology as 'conservative democratic'. The true intentions and future development of this governing party however still remain the subject of an extensive debate in Turkey. There is a more or less clear link between the current AKP and the İttihad-I Muhammedi Furkası (Islamic Unity Party), a political party founded on 5 April 1909. This party operated in the context of a lively political debate which took 
place at the beginning of the Second Constitutional Era (1908-20) of the Ottoman Empire. Its ideology was based on the idea of Islamic reformism, and the party functioned as the most explicit opponent of the Committee of Union and Progress, the main political organisation of the Young Turks. As with the Young Turks, those in the Islamic Unity Party were also keenly aware of the economic, political, and cultural crisis of the Empire, but their proposed remedy was in total contrast to that of the Young Turks. The Islamic revivalist party rejected Westernisation and secularisation and sought to reform the Empire by turning to Islamic traditions (Bulaç 2008). In other words, like the contemporary AKP, the Islamic Unity Party was

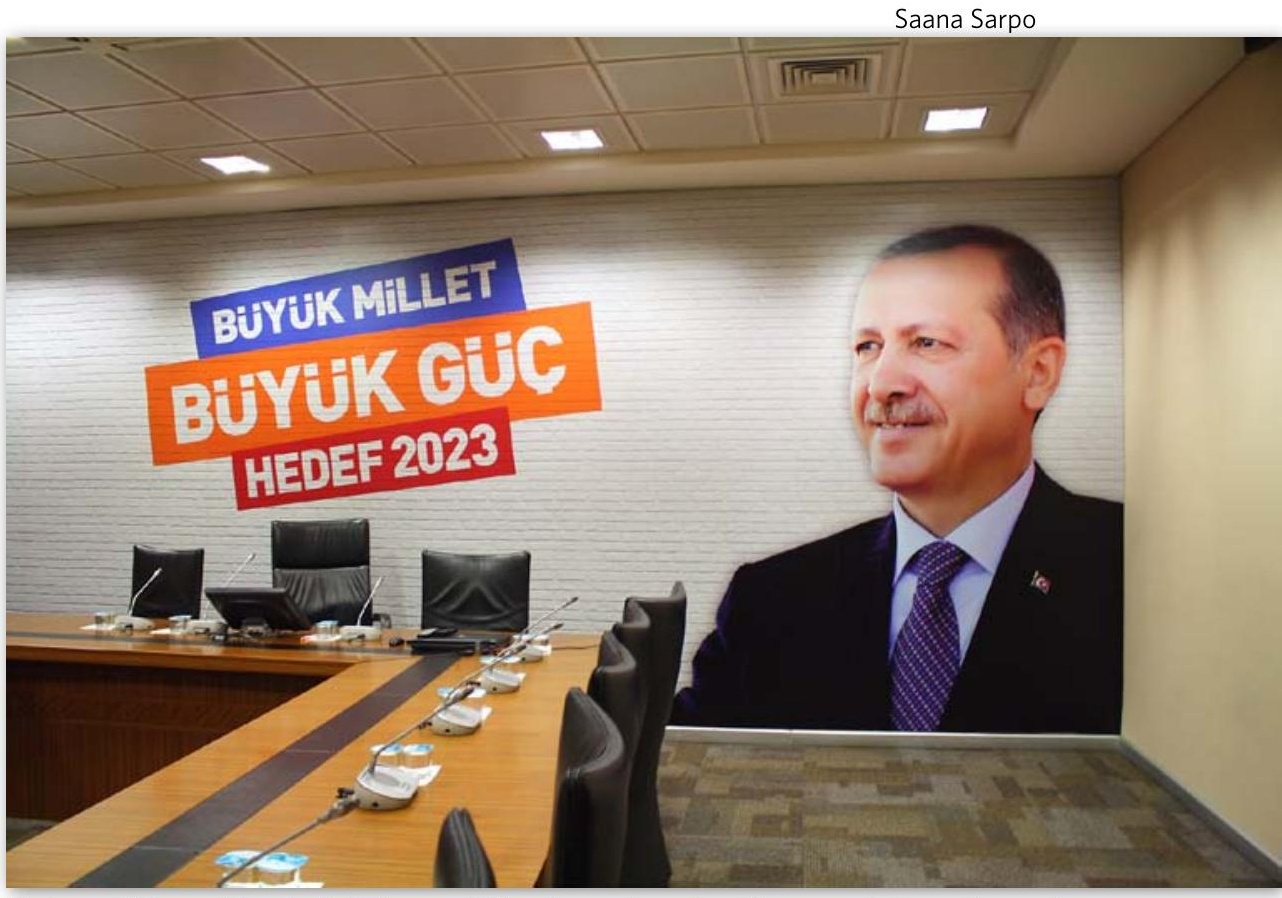

Picture of Recep Tayyip Erdoğan and the slogan 'great nation, great strength, goal 2023', the Justice and Development Party (AKP) headquarters in Istanbul, 2013. not attacking modernity as such but rather sought to build a 'Muslim modernity'. Thus, the social cleavage between secularism and Islam pre-dates the Republic: this latent social division was already being politicised by an Islamic party during the Second Constitutional Era, as much as it was politicised by the radical secularists within the Young Turks.

For much of the preceding ten years, the very discussion of a new, democratic Turkey has been connected with the rise of the AKP (Hale and Özbudun 2010; Kuru and Stepan 2012). All in all, the twelve years of continuous AKP rule has witnessed developments of a very ambiguous nature. In the early years, the party embarked on a wide ranging reform programme that increased civil liberties, reduced the political role of the military, liberalised society and the economy, and allowed for a public discussion about certain perennial problems such as the Kurdish question (Hale and Özbudun 2010). More recently, however, many commentators have noted that the AKP has abandoned its liberal platform, and instead of striving to consolidate a more pluralist and valuefree politics, it has used its unchallenged monopoly of power to embark on a social engineering project that is leadingTurkey into an era of religiously-defined conservatism (Keyman 2010).

The AKP can be seen as a contemporary manifestation of the long-term political struggle between radical modernisation/Westernisation and that of a more conservative attempt to build the aforemen-

tioned 'Muslim modernity', a sociopolitical model that seeks to ground modern organisational and rationalisation processes firmly on the Islamic tradition and its accompanying values (Yavuz 2009). Thus, the (party) political production of a social distinction between secularisation and a religiouslyinspired legitimation of the social order, fully observable during the last decades of the Ottoman Empire, is without doubt an aspect of the contemporary AKP project as it reproduces a conservative and Islamoriented discourse in present-day Turkey. The AKP has mainly built its legitimacy on the idea of representing a pragmatic, non-ideological party which implements good governance, economic growth, and political stability in Turkey. In the AKP's official programme, ${ }^{1}$ all this is presented as a pragmatic project unencumbered by ideological implications. However, there is indeed an ideology being espoused by the AKP, and its traces can also be found in the official programme, although in a de-emphasized form. Further, even though there is very little reference to Turkey's history in the official programme, one can

1 The Justice and Development Party (AKP)'s current programme can be found on the party's official website (see the bibliography). All references to the party programme in this article originate from this document. 
however detect a particular historical interpretation that works as an unquestioned presupposition of the AKP's alleged 'politics of pragmatism'.

According to this programme, Turkey is currently experiencing a widely felt, popular desire for great change. The present is defined through an assertion that concepts have lost their previous meanings and values have degenerated. In this context, Turkey needs a new political party with a fresh understanding, one that relies on 'local but modern knowledge'. After this, Turkey's strengths are listed: its natural resources; young and dynamic population; rich historical and cultural heritage; enduring and strong state tradition, its possession of a spirit of entrepreneurship such as is required in international competition; an important geo-strategic position; plenty of historical and natural attractions for developing a lively tourism sector; and, most significantly, social solidarity and mutual responsibility as reflections of 'our nation's national and religious character' ('halkımızın milli ve dini karakterini').

The AKP's programme thus begins by constructing the image of a nation which is endowed with an eternal, national-religious essence, and then presents the AKP as the instrument of its expression. The seemingly innocent statement of the people possessing particular national and religious characteristics works as a precondition for evaluating how past political practices, ideologies, and institutions have or have not been able to reflect this pre-existing national character. The AKP's conservative ideological core is thus firmly established. After this, Turkey's history can be interpreted from the viewpoint of this conservative perspective. Those practices and institutions that have managed to serve this allegedly naturally existing religious national character become the sites of organic development, whereas historical events and processes in contradiction to it come to be presented as historical mistakes.

According to the programme, the AKP exists in order to offer enduring answers to social problems by aggregating the wisdom provided by tradition and history'. More than anything else, the party wants to 'serve society'. This means that the party does not aim to implement any specific ideology but rather the principles of modern democracy. Turkish society expects that, as a part of a civilised world, rights and freedoms are fully implemented within its borders. This means that the steps the party wants to take on these issues are not because some international organisation expects it, but because all citizens of the Republic are entitled to these rights. All this implies, of course, that according to the AKP, rights and freedoms have hitherto been restricted in Turkey.

In this respect it is rather interesting that the AKP programme refers with approval to Atatürk's principles and reforms ('Atatürk ilke ve inkılaplarmi') and that these are defined as the main tools for bringing Turkey to the level of contemporary civilization. This is followed by asserting that secularism means that all kinds of religious groups can practise their faiths in peace and arrange their affairs accordingly, but it also means that those who do not confess any religious beliefs are also entitled to live as they wish. From this point of view, secularism is the principle that guarantees freedom and social peace. Even further, it is stated that the AKP does not accept the use of holy religious values as a political tool. This sentence can be interpreted as a clear precautionary stance against any possible accusation that the AKP uses religion for political purposes. The whole AKP programme can indeed be interpreted as a document attempting a 'precautionary justification'. The problem with this type of political programme is that, rather than really setting the agenda, it is written in anticipation of possible attacks or accusations coming from its political opponents. In this sense, rather than really defining the political agenda, the AKP programme is defined by a tendency to secure the party's existence in the context of a possible future critique.

After taking a seemingly approving stance towards the principle of secularism, the programme however includes a more or less clear critique of Kemalist secularism. It is stated that the AKP does not approve of a situation where people who are in faith and who are living according to their faith' confront different standards and insulting practices. This rather short passage is actually one of the main indicators of an overall historical interpretation implied but never really explicitly stated by the AKP programme. This historical interpretation is presented in a moderate tone and covered in the liberal-democratic discourse of individual freedom and human rights, but it is there nevertheless: Kemalist ideology with its principle of secularism has, throughout the history of the Republic, repressed pious Muslims. Now this will come to an end. This is not cried out loud in the programme, but it is implied through the assertion that, in the name of secularism, it is not acceptable to insult people's faiths. In other words, if the AKP activists did not think that the Kemalist regime has suppressed pious Muslims, why would they have included this passage in the programme? Clearly, it is there as a veiled attack on the vision of a radical 
modernisation advocated by the Kemalists. Further, it is a marker of a historical mistake, referred to above. The national and religious character of the nation is established as a fact at the beginning of the programme. Within this narrative of 'true national character', the ideal citizens are those who conform to the national and religious character of the nation, and this means that Kemalist secularism and its vision of a radical freedom of modernity has been a mistake in national history, one that will be repaired now that the AKP takes the office of government.

According to the programme, the AKP wants to establish a 'new understanding of politics' in Turkey. Turkey needs a genuine state of law, not a system that prioritises the laws of state. This also, to a very significant degree, implies a specific interpretation of Republican history. It takes a critical stance on one of the main characteristics of the Turkish Revolution; namely, that of creating a modern society by means of revolutionary laws. This is, again, presented as a historical mistake, in contradiction with the conservative ideal of eternal national and religious values. The AKP programme utilises the discourse of freedoms in asserting that this wrong turning must be reversed. The aim is to achieve a liberal society, a state of law where all interests are looked after.

This means composing a new social contract between the state and society, including a new Constitution. It is said, this time explicitly, that the composition of a new Constitution should not be yet another example of 'constitutional social engineering' but about drawing up a new, democratic Constitution by means of consulting the true will of the people. This is of course deeply enmeshed in the overall historical interpretation. It claims in a rather straightforward manner that the republican era has been characterised by an elitist, undemocratic tradition of composing constitutions through the idea of social engineering, a rebuilding of the nation from top to bottom.

The AKP's programme has been written with a consistent usage of a Western-originating liberaldemocratic vocabulary. The reason why previous Islamist politicians have chosen to depart from the discourse of political Islam has much to do with the changing perceptions concerning the West among this circle. Unlike the Turkish Islamist parties, led until recently by Necmettin Erbakan, who perceived the West/Europe as the explicit antithesis of a presumably righteous Islamic civilisation, in their political rhetoric the leaders of the AKP have fully embraced the liberal democratic discourse which goes along with the prospect of EU (Dağ1 2009) membership. It has been well observed by M. Hakan Yavuz (2009) that the AKP has used the liberal democratic discourse and the EU in order to carve out a wider space for the lifestyles and preferences of its core constituency, which is the conservative and religiouslyoriented new middle class. However, at the same time the AKP leadership is very critical of the Westernisation/Europeanisation of Turkey.

But this constituency is not a pre-existing, welldefined social group that always keeps the conservative centre-right party in power in Turkey. The AKP's official programme - all its supposedly value-free, liberal-democratic aspects notwithstanding - still implicitly produces the conservative and religiouslyoriented subject through its historical interpretation. The AKP's institutional memory is laden with narratives of the harassment of pious Muslims, allegedly repressed by the Kemalist modernising elite. The idea of a specifically Islamic modernisation of society predates the establishment of the Republic. The AKP is the most powerful contemporary representative of this political movement. The ultimate goal of the Islamic modernisation movement is to form a coherent sociopolitical bloc by naturalising religion as the core ingredient of a collective political identity. The institutionalised memory represented by the current AKP programme - although, for tactical reasons in disguised form - is that of experiences and ideas gathered during years of opposition, of building the networks and solidarities whose very existence has been part of an attempt to form a coherent conservative constituency.

This analysis is line with the definition proposed by Sezgin (2013: 77), who defines Islamist activism as 'political engagement through the deployment, articulation and interpretation of Islamic sources, traditions, signs and symbols in innovative way in order to form and/or sustain a collective actor and/ or collective action in a given context'. The building of a coherent sociopolitical bloc around the idea of a religious, morally-righteous community (within the context of modernity) in order to secure a mass following did not begin in the 1980 s with Turgut Özal's Motherland Party, or during the 1950s with Adnan Menderes' Democrat Party, but already in 1908 with the founding of the Islamic Union Party. Thus, the (party) political production of an Islamist-Secularist division started together with the modernisation processes within the Ottoman realm, and was already in full usage by the beginning of the establishment of the Republic. There was, of course, a traditional, 
religiously-oriented majority living in Ottoman Anatolia at the beginning of the twentieth century. But the articulation of this group's collective political identity has required political organisation to bring these separate communities together in order to gain their support in general elections.

The retelling of the story of oppressed pious Muslims in Turkey functions as the most salient and enduring narrative trope within the AKP. In the AKP's official programme this takes place by first establishing the nation as a community with an essence in the sentence 'our nation's national and religious character. This is followed by different examples of current social problems, alluding to the idea that the country's sociopolitical problems stem from the a detrimental effects of attempts at 'social engineering. The retelling of the common narrative trope - in which Kemalist secularism oppresses pious Muslims - is now embedded in the universal language of liberal democracy, individual freedoms, and human rights.

A commitment to economic liberalism, on the other hand, is used to form an alliance between Turkey's business circles and liberal intellectuals. This results in the production of a social cleavage, not between economic classes, ethnic groups, nationalists and cosmopolitans, but along the lines of lifestyles and religious adherence. The political adversary thus constructed is the radical secularist (Kemalist) social group, depicted as the historical oppressor of the 'genuine nation'.

There indeed seems to be a blind spot in the current literature when it comes to the cause and effect logic in the production and ontological nature of social cleavages. In Turkey's case, Yavuz (2009: 105) asserts that 'Although the AKP sought to become a "catch-all" party of the centre-right, the issue of Islamic lifestyle is very important for the core. Thus, even as brilliant an observer as Yavuz presents this issue in a way which implies that the nature of 'values' and the 'social' are givens, and that the party simply has to take these into consideration while defining its ideology and concrete policies. What is being totally ignored is the obvious fact that these conservative and Islamist-oriented values (and the collective identity allegedly defined by them) are purposefully and intentionally generated by a long line of conservative centre-right and Islamist parties stretching back more than a century, in their attempt to build a coherent sociopolitical bloc as the basis of mass support.

\section{The CHP and the production of secular constituency}

The Republican People's Party (CHP) occupies a very specific place in the political history of Turkey. It can be termed a 'regime-founding' party and in a peculiar sense, this position is at the same time the reason both for its relative success and its failure. The party was founded on 9 September 1923 by Mustafa Kemal Atatürk based on the Societies for the Defence of Rights, the organisational structure of the Anatolian Resistance Movement which took place during the period 1919-23. One of the most controversial historical debates in Turkey concerns the 'correct' interpretation of the Kemalist one-party era: was this a necessary phase in the building of a new, modern nation state after centuries of Islamic theocracy, a phase when political liberties had to be limited in order to create the necessary structural preconditions for a full-blown pluralist democracy, or was this an essentially authoritarian and even totalitarian regime that forcefully imposed its ideology upon a reluctant society? Obviously, these opposing historical interpretations reside at the very core of the intertextuallyreproduced social cleavages.

The ideas that guided the state-building project from 1919 all the way to the 1930s, synthesized as the six principles of Kemalism, have always guided the ideology of the CHP. The CHP is the party whose function it has been to implement a cultural revolution after the political revolution had been realised with the establishment of the Republic in 1923. What is thus significant for our purposes is that the CHP functions as the political organisation which strives to implement in Turkey the imaginary of radical freedom $^{2}$ inherent in modernity. By advocating the Jacobin vision of secularisation, the CHP is the main protagonist in the process that produces the Islamist-secularist cleavage in Turkey.

It is widely accepted that Kemalism continues the Westernising and secularising tendencies of the late Ottoman Empire, especially the Young Turk movement. Kemalism can thus be seen as a radicalised version of earlier reform attempts in the new context of

2 Gerard Delanty and Patrick O’Mahony (2002: 6) argue that underlying the main cultural models of modernity - such as knowledge, power and the self there is a discourse of radical freedom, which, on the other hand, can take authoritarian, romantic, liberal and collectivist forms. As they put it, 'at the heart of the modern cultural model is the quintessentially liberal and post-Christian view that human societies are incomplete and that human nature is endlessly capable of perfectibility'. 


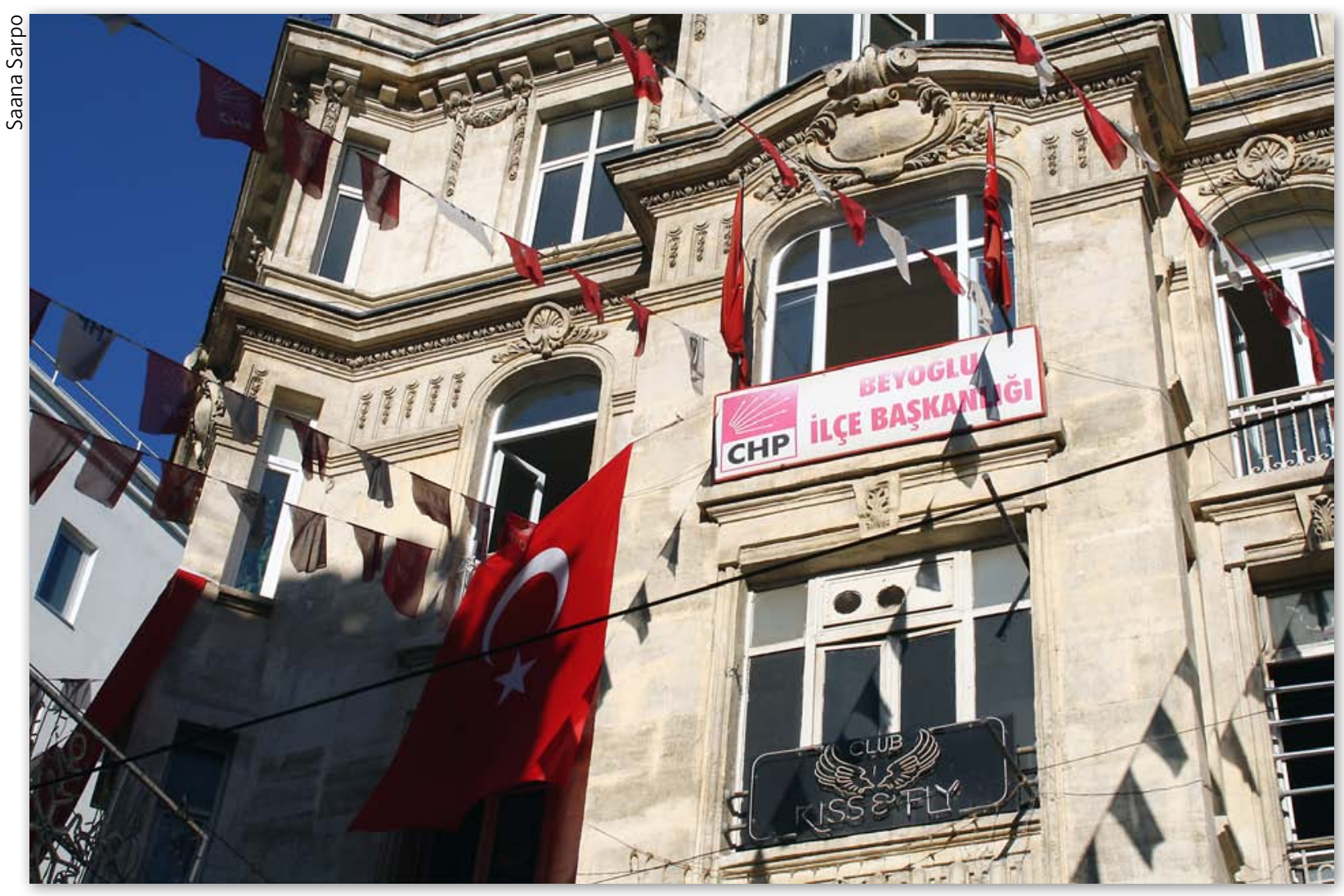

Outside the Republican People's Party (CHP) office in Beyoğlu, Istanbul, 2013.

the nation state. The CHP has naturally gone through many different phases from 1923 to the present day. After the abolishment of the one-party regime, the CHP was forced to redefine its ideology in the context of a competitive parliamentary democracy. By the middle of the 1960s, this 'soul-searching' reached at least a partial conclusion when the party was refashioned as being left-of-centre, subsequently being defined as a social-democrat party. Recently an ongoing discussion has taken place, both within the party itself as well as in wider circles, concerning the possibility of making a workable ideological synthesis between Kemalism and social democracy (Alaranta 2014; Ciddi 2009; Ayata and Ayata 2007; Güvenç 2002).

The CHP's programme ${ }^{3}$ sets out by declaring that the party is the guardian of Atatürk's principles. After this, it is proudly stated that the 'Defence of Rights Organisations' (Müdafaa-i Hukuk Cemiyetleri), that

3 The Republican People's Party's (CHP) current programme can be found on the party's official website (see the bibliography). All references to the party programme in this article originate in this document. were the foundation of the Anatolian Resistance Movement, represented the first successful national liberation struggle against imperialism. The CHP was founded as a direct continuation of the Defence of Rights Organisation of Anatolia and Rumelia by Mustafa Kemal Atatürk on 9 September 1923. Thus, the party pre-dates the Republic, which was established on 29 October 1923. There is a general tendency within CHP circles to see the Sivas Congress, the second major meeting of the Anatolian Resistance Movement, as the first Congress of the CHP (Bilâ 2008: 14). All this is highly significant in terms of the institutional memory of the CHP because it depicts the Anatolian Resistance Movement as the pre-historical embodiment of the Republic, with the CHP being the link between the two. This narrative suggests that the purpose of the Anatolian Resistance Movement was to establish a secular Republic of Turkey. This has been underscored by Erik J. Zürcher (1998) who argues that this narrative distorts historical reality because the actors involved in the Anatolian Resistance Movement aimed to secure the traditional rights of the Muslim communities and the continuing existence of the Ottoman Caliphate, not the foundation of a new, secular Republic. 
Within the CHP, however, this narrative is not challenged because it was narrated by Atatürk himself, especially in his famous six-day speech of 1927 , and it has become the main, even constitutional aspect of the CHP's institutionalised memory. The reforms, known collectively as the 'Atatürk Revolution' (Atatürk Devrimleri) are conceptualised in the $\mathrm{CHP}$ programme as the philosophical and ideological basis of the CHP. These reforms establish a modern, secular Republic, based on the ideas of freedom for citizens, popular sovereignty, and a commitment to a project of establishing a modern society. Further, these reforms ended the elitist imperialist system, which characterised Turkey's underdevelopment. All in all, the reforms introduced by Mustafa Kemal represent the continuation of the Enlightenment Revolution (Aydinlanma Devrimi) in Turkey.

After this, the significance of the 'six arrows': the ideological foundations of the party, are explained one by one. I will here present three of these principles which most clearly reveal the implicit historical interpretation presupposed by the CHP. Republicanism (cumhuriyetçilik) is defined as 'the greatest transformation in our history', as it abolished the concept of a sultanate and established a form of government based on popular sovereignty. The idea of a national will inherent in republicanism includes the whole nation, both those in government and those in opposition. Further, republicanism implies that a religious community has been replaced by modern citizenship.

Nationalism (milliyetçilik), as it is espoused by the CHP, is 'Atatürk's nationalism', an official state nationalism, which emphasises the idea that the Republic is based not on religious, racial, or ethnic similarities but on a common, shared political consciousness. This is similar to the idea of republican nationalism, or civic nationalism advocated in France. Further, the nationalism espoused by the CHP is defined by its egalitarian ethos. According to this view, all citizens are equal before the law, irrespective of their faith, mother language, ethnicity, gender, or any other such basis. Further, it means that the state is not ethnically defined, and that the state remains neutral in terms of the various ethnic groups composing the nation. Thus, the definition of republicanism and nationalism implies that prior to the institution of the Republic there had been an elitist Ottoman imperial regime based on the idea of an Islamic community. This was replaced by a nation composed of free individuals, who came from different backgrounds to form a new community based on equal citizenship.

The principle of secularism (laiklik) is of utmost importance in producing a secularist constituency. At first sight there seems to be little difference in the definition of this principle between the parties. The CHP programme defines secularism as a separation between the state and religious affairs. It is defined as the cornerstone of the freedom of religion and consciousness, a principle according to which the representatives of different faiths and outlooks are able to live peacefully, side by side. Thus, it is the foundation of the Republic and democracy. After this, however, crucial differences start to emerge. It is stated in the CHP programme that secularism presupposes that not only state and legal institutions, but also society in general operates through secular principles, and that education is secular as well. Most significantly, according to the CHP, the main goal of secularism is the 'liberation of reason'. Of equal importance, it is explicitly stated in the CHP programme that religion is part of the private, not of the public sphere of life.

It is extremely important to notice that nothing of this kind in terms of secularism is stated in the official programme of the AKP. Quite to the contrary, the main historical interpretation expressed in the AKP programme asserts that Kemalist secularism, as part of the authoritarian state ideology, has oppressed pious Muslims. The narrative of pious Muslims being liberated from 'unnatural' and repressive secularism is at the core of the historical interpretation shared by all Islamic-conservative parties in their attempt to build a coherent sociopolitical bloc. The idea of secularism as a tool for liberating human reason, inherent in the CHP programme, is based on an altogether different emancipation narrative, one that is firmly based on the European Enlightenment tradition. As was noted, this idea of secularism originating from the Enlightenment era is one of the main components of the Jacobin idea of a radical imaginary of freedom within modernity, as a site of perpetual social progress founded on human rationality.

Thus, the principle of secularism, conceptualised as the liberation of human reason, manifests the implied historical interpretation of the 'Atatürk Revolution', conceptualised as the Turkish manifestation of a universal emancipation project. According to this narrative, for centuries human reason was suppressed and violated by the forces of tradition, religious dogmas being the most significant obstacle in the way of the free exercise of human reason. This historical narrative also implies that in the Ottoman Empire, the Islamic faith and practices functioned as a dogmatic tool in legitimising an undisputedly elitist system in which the Ottoman dynasty and religious 
establishment wielded power over the ignorant, uneducated masses. Within this historical interpretation, the 'Atatürk Revolution' is one of the great revolutions of the modern era, a transforming project of world-historical significance that established, at one stroke, all aspects of European modernity within a heretofore backward, traditional Islamic society.

The same kind of process of interpellation that was detected in terms of an Islamic conservative constituency can be observed with the CHP and the national identity which has been internalised by the secular middle classes in Turkey. Whereas the Islamic-conservative identity is generated through an historical narrative that presents the story of an enduring Turkish nation as being composed of 'our national and religious values', the secularist national identity is produced by the historical narrative of the 'Atatürk Revolution'. The Enlightenment and its utopian vision of a new human being and a new society, created with the help of human reason finally discovering its true powers, forms the basic narrative trope in the secularist interpretation. Within the secularist discourse, the Turkish Revolution is constantly framed as the Turkish Enlightenment (Türkiye Aydinlanmasi) and as an attempt to create a new human being, freed from the shackles of traditional religion (Selçuk 2006). In a paradoxical sense, then, the attempts by competing political parties to form coherent sociopolitical blocs are based on two conflicting narratives of 'liberation'. In the conservativeIslamic interpretation of the Republic's history, the interpellated subject is a pious Muslim who has been liberated from an oppressive, elitist, intolerant, and artificial secularist ideology. In the opposing narrative, the interpellated secular subject is being freed from a dogmatic, backward, and repressive religious traditionalism.

The institutional memory within the CHP recurrently reproduces the idea of a party specifically established by Mustafa Kemal Atatürk to implement and forever defend the ideals of the Turkish Revolution. The safeguarding of this task thus becomes the main component of the self-representation of the CHP. This institutional memory defines the CHP as the state-founding party, one that is forever the true representative of the original revolutionary ideals of the Atatürk Revolution. However, the institutional memory of the CHP extends further into the past than the Anatolian Resistance Movement and the establishment of a secular republic by Atatürk. It includes several layers of previous historical interpretations, especially those of the Second Constitutional Era and its immediate predecessor, the Islamic autocracy of Sultan Abdülhamid II. These previous ideas and experiences, constituting the idea of a struggle between modernisers and their traditionalist opponents, occupy a pre-Republican narrative layer within the CHP. In addition to the memories of the Young Turks and their Islamic opponents in the late Ottoman era, there is the memory of a great sense of loss and disillusionment which was experienced with the end of the Kemalist one-party era and the Democrat Party's victory in the first free elections in 1950, an era that has produced memories of great confusion and incredulity among the CHP cadres (Bilâ 2008: 123). These memories of being rejected by the popular vote still haunt the CHP today.

A third major layer of the institutional memory of the CHP concerns the decades-long attempt to become a social democratic party. In previous literature the social democratic identity of the CHP is usually seen as problematic, the main suggestion being that the CHP's insistence on making a workable synthesis between Kemalism and social democracy is untenable and contradictory. Sinan Ciddi (2009: 103) argues that the reason for this contradiction - and for the CHP's weak electoral performance - is the party's commitment to the modernist paradigm inherent in Kemalism, that is to say, the CHP's social democratic posture is obstructed by the ideological and authoritarian position resulting from the party's reliance on certain 'classical tenets of modernity'. On the other hand, Murat Belge (2009) argues that the Turkish left has never been an independent force in politics, as it was from early on 'embraced to death' by Kemalism. All these critical evaluations suggest that the relationship between Kemalism and social democracy has not produced a generally accepted synthesis.

The current CHP programme can be read as a record of the party's various experiences across different eras stretching from the pre-republican period to the present. Ideological soul-searching within the party is crucially about what different interpretations can be formulated from the dominant layer of memory that defines the party as the guardian of the Atatürk Revolution. This presiding idea of the party's mission expresses itself in its historical rationale which is used to interpellate the secular subject and national identity as the basis of party's mass support. In other words, the entire range of ideas and experiences from different eras finally come together to produce the image of a state-founding party implementing a great revolution (a secularist emancipation project promised by modernity) in Turkey. 


\section{Concluding remarks}

The attempt to generate a coherent sociopolitical bloc based on a common denominator stems from the requirements of legitimation within the democratic system. Within this system, legitimate power is based on the idea of representing the will of the nation, and a certain 'populist' logic is thus inherent in democracy. As the nation is proclaimed the true possessor of sovereignty, the characteristics of the nation become a key issue. In Turkey, there are two opposing traditions for building a modern state: one strives for radical modernisation, the other favours an Islamic modernity. As the powerful central state remained intact during the transformation from Empire to Republic, the legitimation of its powers was based on the idea that it represented the will of the nation. The Kemalists won the internal power struggle in the wake of the Anatolian Resistance Movement, and they were able to turn the state apparatus into the instrument of a radical modernisation project. Later on, the right of the Kemalist state elite to rule Turkey was challenged by the centre-right parties. As part of their challenge, they increasingly started to emphasise that there was a conservative Muslim majority in Turkey, whose values were being repressed by the secularist state. While doing this, these parties could build on the tradition of an Islamic political articulation that lingered on from the pre-Republican period.

There is thus nothing inevitable in the idea that the Islamist-secularist cleavage should have become the main social cleavage in Turkey. There is no such thing as a 'social' basis prior to political articulation that should have rendered the distinction between Islam and secularism as society's main line of division. This social cleavage was intentionally generated first at the beginning of the twentieth century with the foundation of political parties aiming to define the 'true' nature of the nation in the context of the formation of a new nation state. This has led to a situation where the struggle for control of the state apparatus is grounded on an attempt to build mass support and thus democratic legitimacy on a common denominator. For the Republican People's Party this common denominator is the emancipation project advocated by Atatürk. For the Justice and Development Party it is Islam.

The representations of the national past by Turkey's two main parties generate different group identities in order to form easily recognizable images of who 'we' are, and what are 'our' essential values, needs, and purposes. It is important to emphasise that these narratives have from their very beginning been produced by the political parties. In the case of Turkey, the social divisions existing today are products of modernisation processes and are thus deeply implicated in the political parties' process of formation that took its first, organised, competitive form during the Second Constitutional Era. It is thus inaccurate to claim that existing social cleavages created political parties to represent these cleavages.

The main social cleavage existing today in Turkey - secularism vs. Islam - is produced and experienced within the modern, centralised state, where political power takes place within the system of competitive politics. In this sense currently existing social divisions are brought about by the process of modernisation, and these divisions are played out within a society that is in its very essence a politicised one. As soon as it is declared that sovereignty resides in the people and not in the person of a sultan (or, ultimately, God), the question of the true will of that rhetorically omnipotent body, 'the people', is immediately posed. This is why it can be claimed that within the context of modernity - and modern political structures where the legitimation of power is based on the idea of representing the popular will - the collective identities based on ethnicity, religion, and ideology are qualitatively different from any previous forms they may have had.

Toni Alaranta is a Doctor of Social Sciences, at the University of Helsinki (2012). Dr Alaranta has subsequently conducted his post-doc studies at the Middle East Technical University in Ankara, and at the University of Tallinn. Currently working as a Senior Research Fellow at the Finnish Institute of International Affairs, his main field of interest is Turkish politics and history. Alaranta has published his articles in Turkish Studies, Turkish Journal of Politics and Turkey Analyst, and he is a regular commentator on Turkey in the major Finnish dailies. His most recent publications include Contemporary Kemalism: From Universal Secular-Humanism to Extreme Turkish Nationalism (Routledge 2014). Email: toni.alaranta(at)fiia.fi

\section{Bibliography}

Adalet ve Kalkınma Partisi, 2014. Adalet ve Kalkınma Partisi Programi, available online at $<\mathrm{http}$ ://www. akparti.org.tr/site/akparti/parti-programi\#bolum $>$ (accessed 1.1.2014)

Alaranta, Toni, 2014. Contemporary Kemalism: from Universal Secular-humanism to Extreme Turkish Nationalism (London, Routledge) 
Allen, Graham, 2006. Intertextuality (London, Routledge)

Althusser, Louis, 1993. Essays on Ideology (London, Verso)

Amorin Neto, Octavio, and Gary W. Cox, 1997. 'Electoral institutions, cleavage structures and the number of parties', American Journal of Political Science 41(1), 149-74

Atasoy, Y1ld1z, 2009. Islam's Marriage with Neoliberalism: State Transformation in Turkey (Houndmills, Palgrave MacMillan)

Ayata, Sencer, and Ayşe Ayata, 2007. 'The center-left parties in Turkey', Turkish Studies 8(2), 211-32

Belge, Murat, 2009. 'Nationalism, democracy and the left in Turkey', Journal of Intercultural Studies 30(1), 7-20

Bilâ, Hikmet, 2008. CHP 1919-2009 (Istanbul, Doğan Kitap)

Bulaç, Ali 2008. 'Kültür Müslümanlığı Ve İttihad-I Muhammedi', Timeturk, 23.5.2008, available online at <http://www.timeturk.com/tr/makale/ali-bulac/ kultur-muslumanligi-ve-ittihad-i-muhammedi.html> (accessed 2.5.2014)

Ciddi, Sinan 2009. Kemalism in Turkish Politics: The Republican People's Party, Secularism and Nationalism (London, Routledge)

Cumhuriyet Halk Partisi, 2014. 'Cumhuriyet Halk Partisi Programi', available online at <http://www.chp.org. tr/wp-content/uploads/chpprogram.pdf $>$ (accessed 1.1.2014)

Dağı, İhsan, 2009. 'Beyond the clash of civilizations: the rapprochement of Turkish Islamic elite with the West' in Clash or Cooperation of Civilizations? Overlapping Integration and Identities, ed. Wolfgang Zank (Farnham, Ashgate), 43-63

Delanty, Gerard, and Patrick O’Mahony, 2002. Nationalism and Social Theory: Modernity and the Recalcitrance of the Nation (London, Sage)

De Leon, Cedric, Manali Desai, and Cıhan Tuğal, 2009. 'Political articulation: parties and the constitution of cleavages in the United States, India, and Turkey', Sociological Theory 27(3), 193-219

Gallagher, Michael, Michael Laver, and Peter Mair, 1992. Representative Government in Western Europe (New York, McGraw-Hill)

Güvenç, Nazım 2002. Yine, Yeni, Yeniden CHP (Istanbul, Anahtar Kitaplar)

Hale, William, and Ergun Özbudun, 2010. Islamism, Democracy and Liberalism in Turkey: The Case of the AKP (London, Routledge)

Halliday, Fred, 2005. The Middle East in International Relations: Power, Politics and Ideology (Cambridge University Press)

Hay, Colin, 2002. Political Analysis: A Critical Introduction (Houndmills, Palgrave MacMillan)

Hodgkin, Kathrin, and Susannah Radstone, 2003. 'Introduction: contested pasts' in Contested Pasts: The Politics of Memory, ed. Katherine Hodgkin and Susannah Radstone (London, Routledge), 1-22

Keyman, E. Fuat, 2010. 'Modernization, globalization and democratization in Turkey: the AKP experience and its limits', Constellations 17(2), 312-27

Kuru, Ahmet T., and Alfred Stepan (eds), 2012.

Democracy, Islam, and Secularism in Turkey (New York, Columbia University Press)

Lee, Robert D. 2010. Religion and Politics in the Middle East: Identity, Ideology, and Institutions (Boulder, Westview Press)

Lipset, Seymour M., and Stein Rokkan, 1967. Cleavage Structures, Party Systems, and Voter Alignments: An Introduction (New York, Free Press)

Scholes, Robert, 1975. 'Cognition and the implied reader', Diacritics 5(3), 13-15

Selçuk, İlhan 2006. 'Türkiye Aydınlanması: Yeni İnsan'ı Yaratmak' in Türkiye'de Aydinlanma Hareketi, ed. Server Tanilli (Istanbul, Akım), 31-7

Sezgin, İpek Gencel, 2013. 'How Islamist parties emerge: the case of the National Order Party' in Negotiating Political Power in Turkey: Breaking up the Party, ed. Élise Massicard and Nicole F. Watts (London, Routledge), 77-98

Yavuz, M. Hakan, 2009. Secularism and Muslim Democracy in Turkey (Cambridge University Press)

Zürcher, Erik J., 1998. Turkey: A Modern History (London, I. B. Tauris) 